\title{
KINERJA STRUKTUR SISTEM TUNGGAL DAN GANDA DENGAN PERFORMANCE BASED DESIGN
}

Abstract

The structure of a simple rental apartment building of the Sumatran Technology Institute had been modeled using the Performance Based Design method. The aim of this study was to obtain the base shear and maximum displacement as well as the performance level of the building structure models in resisting the combination of gravitation and lateral earthquake loads. The loads were based on the function and location of the building. The building structures had been designed as a double system, namely the beam-column frames and shear walls in the direction of the $\mathrm{XZ}$ and $\mathrm{YZ}$ axis. There were four models: the models with a double system according to the original design, the beam-column frames without XZ shear walls, the beam-column frames without YZ shear walls, and the beam-column frames without shear walls. The results of the analysis at the performance level showed that the model with a double system was able to resist the highest base shear while the frames system without shear walls was only able to resist the lowest base shear compared to other models. The inter story drift under earthquake loads in the direction of the $\mathrm{X}$ and $\mathrm{Y}$ axis showed that all models of structural system were still within the safe limit.

Key Words: dinding geser, performance based design, pushover, tingkat kinerja, titik kinerja.

\section{PENDAHULUAN}

Analisis kinerja suatu struktur gedung terhadap beban gempa dapat dilakukan dengan empat cara, yaitu: statik linier, statik nonlinier, dinamik linier, dan dinamik nonlinier. Cara statik nonlinier dikenal sebagai analisis pushover. Prinsip analisis pushover adalah dengan memberikan beban lateral pada struktur sehingga terjadi perpindahan lateral dalam bentuk kurva kapasitas. Beban tersebut ditingkatkan sehingga sendi-sendi plastis muncul pada pangkal pangkal balok dan kolom. Kondisi ini membuat perilaku struktur berubah dari elastis menjadi nonelastis. Karena terjadi perubahan perilaku struktur, maka kurva kapasitas hubungan gaya geser dasar dan perpindahan lateral berubah dari kondisi linier menjadi nonlinier. Pada analisis dengan metode performance based design (desain berdasarkan kinerja), data beban gempa berupa spektra respons dibandingkan dengan kurva kapasitas untuk memperoleh titik kinerja dan tingkat kinerja struktur.

Tujuan penelitian ini adalah untuk memperoleh tingkat kinerja struktur dalam menahan kombinasi beban gravitasi dan beban lateral gempa dengan cara performance based design. Dalam penelitian ini, studi kasus berupa struktur bangunan gedung rumah susun sewa (rusunawa) Institut Teknologi Sumatera (Itera) yang menggunakan sistem ganda (rangka beton bertulang dan dinding geser).
Penentuan kinerja pada model-model struktur dilakukan dengan menggunakan perangkat lunak Structural Analysis Program (SAP). Model pertama adalah berdasarkan as built drawing struktur gedung. Model kedua dan ketiga adalah struktur gedung dengan perbedaan jumlah dan arah dinding geser. Model keempat adalah sistem rangka tanpa dinding geser. Perbedaan model adalah untuk menentukan kinerja terbaik terhadap beban gempa.

\section{METODOLOGI}

Pada analisis pushover, perilaku struktur berubah sesuai dengan beban yang terus ditingkatkan seperti yang diperlihatkan pada Gambar 1. Hasil analisis pushover berupa kurva kapasitas, yaitu hubungan antara gaya geser dasar $(V)$ dengan perpindahan lateral di atap bangunan $\left(\delta_{\text {atap }}\right)$. Immediate Occupancy (IO) adalah kondisi kerusakan struktur yang terbatas pasca gempa. Kinerja struktur hampir tetap sama dengan kondisi sebelum gempa, sehingga struktur tetap dapat digunakan. Life Safety (SF) adalah kondisi kerusakan signifikan pasca gempa; sebagian struktur yang tidak siginifikan runtuh, sehingga menyebabkan bahaya pada pengguna bangunan, tetapi tidak sampai meyebabkan kehilangan jiwa. Structural Stability (SS) adalah kondisi kerusakan pasca gempa yang menyebabkan struktur runtuh sebagian atau total. Kerusakan yang substansial menyebabkan 
penurunan kekakuan dan kekuatan pada sistem penahan beban lateral, tetapi sistem penahan beban gravitasi masih memiliki kekuatan. Tingkat kerusakan berat menyebabkan perbaikan struktur tidak dapat dilakukan.

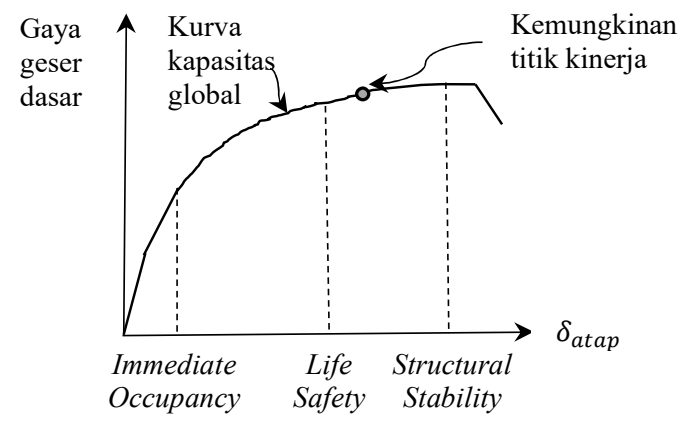

Gambar 1. Kurva kapasitas hasil analisis pushover (CSSC, 1996)

Dalam analisis performance based design, kurva kapasitas hasil analisis pushover diubah menjadi spektrum kapasitas yang merupakan hubungan antara percepatan spektra $\left(S_{a}\right)$ dengan perpindahan spektra $\left(S_{d}\right)$ dengan menggunakan persamaan (1) sampai dengan (4) (CSSC, 1996):

$$
\begin{gathered}
M P F_{1}=\left[\frac{\sum_{i=1}^{N}\left(w_{i} \phi_{i 1}\right) / g}{\sum_{i=1}^{N}\left(w_{i} \phi_{i 1}^{2}\right) / g}\right] \\
\alpha_{1}=\frac{\left[\sum_{i=1}^{N}\left(w_{i} \emptyset_{i 1}\right) / g\right]}{\left[\sum_{i=1}^{N}\left(w_{i} / g\right)\right]\left[\left(w_{i} \phi_{i 1}^{2}\right) / g\right]} \\
S_{a}=\frac{V / W}{\alpha_{1}} \\
S_{d}=\frac{\Delta_{\text {atap }}}{P F_{1} \phi 1_{1, \text { atap }}}
\end{gathered}
$$

dengan:

$M P F_{1}$ : faktor partisipasi modal untuk mode alami pertama

$\alpha_{1} \quad$ : koefisien massa modal pada mode pertama

$w_{i} / g$ : massa pada tingkat ke-i

$\phi_{1, i} \quad$ : amplitude mode-1 pada tingkat ke-i

$\phi_{1, \text { atap }}$ : amplitude mode-1 di atap

$N \quad$ : jumlah tingkat bangunan

$V \quad$ : gaya geser dasar

$W \quad$ : berat bangunan (termasuk beban sendiri dan beban hidup)

$\Delta_{\text {atap }}:$ perpindahan atap

$S_{a} \quad$ : percepatan spektra

$S_{d} \quad$ : perpindahan spektra

Beban aktual gempa dimasukkan dalam pemodelan berupa spektra respons yang sesuai dengan jenis tanah dan lokasi struktur bangunan. Spektra respons merupakan hubungan antara periode $(T)$ dengan percepatan spektra. Dalam analisis performance based design, spektra respons diubah menjadi spektrum keperluan (demand) yang merupakan hubungan antara percepatan spektra dengan perpindahan spektra dengan menggunakan persamaan (5) sampai dengan (7) (CSSC, 1996):

$$
\begin{aligned}
& S_{d i}=\frac{T_{i}^{2}}{4 \pi^{2}} S_{a i} g \\
& S_{a i} g=\frac{2 \pi}{T_{i}} S_{v i} \\
& S_{d i}=\frac{T_{i}}{2 \pi} S_{v i}
\end{aligned}
$$

dengan:

$S_{d i} \quad$ : nilai spektra perpindahan pada periode ke-i

$S_{a i} \quad$ : nilai spektra percepatan pada periode ke-i

$S_{v i} \quad$ : nilai spektra kecepatan pada periode ke-i

$T_{i} \quad$ : periode i

$g \quad$ : percepatan gravitasi

Dengan demikian, spektrum kapasitas dan spektrum keperluan dapat diplot karena mempunyai acuan yang sama, yaitu berupa kurva hubungan spektra percepatan dan spektra perpindahan. Titik

\begin{tabular}{|c|c|c|}
\hline $\begin{array}{l}\text { Operational } \\
\text { (O) }\end{array}$ & $\begin{array}{l}\text { Tingkat } \\
\text { sangat } \\
\text { ringan }\end{array}$ & $\begin{array}{l}\text { Tidak ada penyimpangan permanen. } \\
\text { Struktur secara substansial } \\
\text { mempertahankan kekuatan dan } \\
\text { kekakuan asli. Retak kecil pada fasad, } \\
\text { partisi, dan langit-langit serta elemen } \\
\text { struktural. Semua sistem penting untuk } \\
\text { operasi berfungsi normal. }\end{array}$ \\
\hline $\begin{array}{l}\text { Immediate } \\
\text { Occupancy } \\
\text { (IO) }\end{array}$ & $\begin{array}{l}\text { Tingkat } \\
\text { ringan }\end{array}$ & $\begin{array}{l}\text { Tidak ada penyimpangan permanen. } \\
\text { Struktur secara substansial } \\
\text { mempertahankan kekuatan dan } \\
\text { kekakuan asli. Retak kecil pada fasad, } \\
\text { partisi, dan langit-langit serta elemen } \\
\text { struktural. Elevator dapat digunakan } \\
\text { kembali. Proteksi kebakaran dapat } \\
\text { dioperasikan. }\end{array}$ \\
\hline $\begin{array}{l}\text { Life Safety } \\
\text { (LS) }\end{array}$ & $\begin{array}{l}\text { Tingkat } \\
\text { sedang }\end{array}$ & $\begin{array}{l}\text { Terdapat sisa kekuatan dan kekakuan } \\
\text { di semua tingkat lantai. Elemen } \\
\text { pemikul beban gravitasi berfungsi. } \\
\text { Tidak ada kegagalan keluar bidang } \\
\text { pada dinding atau ujung tembok } \\
\text { pembatas. Terdapat beberapa } \\
\text { penyimpangan permanen dan } \\
\text { kerusakan partisi. Bangunan mungkin } \\
\text { tidak dapat diperbaiki secara } \\
\text { ekonomis. }\end{array}$ \\
\hline $\begin{array}{l}\text { Collapse } \\
\text { Prevention } \\
\text { (CP) }\end{array}$ & $\begin{array}{l}\text { Tingkat } \\
\text { berat }\end{array}$ & $\begin{array}{l}\text { Terdapat sedikit sisa kekakuan dan } \\
\text { kekuatan, tetapi kolom dan dinding } \\
\text { penahan beban tetap berfungsi. Akses } \\
\text { keluar bangunan rusak, terdapat } \\
\text { perpindahan permanen besar, } \\
\text { keruntuhan tembok pembatas yang } \\
\text { tidak diikat, dan bangunan hampir } \\
\text { runtuh. }\end{array}$ \\
\hline
\end{tabular}
perpotongan antara spektrum kapasitas dengan spektrum keperluan adalah titik kinerja struktur yang memperlihatkan tingkat kinerja bangunan dalam menahan beban gempa. Tingkat kinerja bangunan diperlihatkan pada Tabel 1 .

Tabel 1. Tingkat kinerja bangunan (ASCE, 2000) 


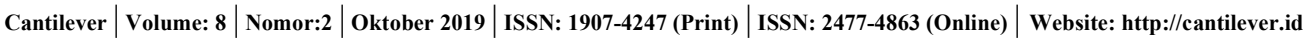
Nurjannah, dkk. / Kinerja Struktur Sistem Tunggal Dan Ganda Dengan Performance Based Design

Pada saat menerima beban gempa, struktur akan memasuki kondisi leleh (titik B) pada sendi-sendi plastis, kemudian berlanjut pada kondisi IO, LS, dan CP. Kekuatan nominal struktur tercapai pada titik $\mathrm{C}$ yang merupakan kondisi runtuh (collapse). Setelah melewati kondisi nominal, kekuatan struktur menurun sampai pada titik D, dan akan terus mengalami perpindahan yang membesar sampai mencapai titik E seperti yang diperlihatkan pada Gambar 2 dan Tabel 2.

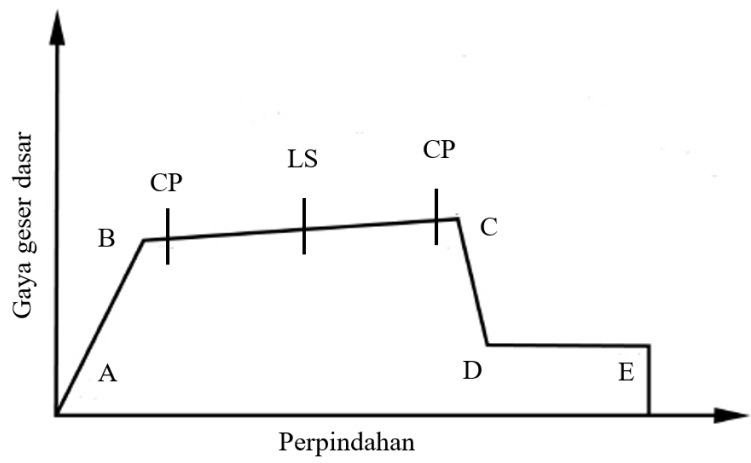

Gambar 2. Kriteria penerimaan perpindahan komponen atau elemen (ASCE, 2000)

Tabel 2. Kriteria penerimaan berdasarkan tingkat kinerja struktur

\begin{tabular}{ll}
\hline Titik & Tingkat kinerja \\
\hline $\mathrm{B}$ & Leleh \\
$\mathrm{IO}$ & Immediate Occupancy \\
$\mathrm{LS}$ & Life Safety \\
$\mathrm{CP}$ & Collapse Prevention \\
$\mathrm{C}$ & Collapse (kekuatan nominal) \\
$\mathrm{D}$ & Reduced strength (penurunan kekuatan) \\
$\mathrm{E}$ & Zero strength (tanpa kekuatan) \\
\hline
\end{tabular}

Untuk menentukan titik kinerja, tipe perilaku struktur ditentukan berdasarkan pada Tabel 3 .

Tabel 3. Tipe perilaku struktur (CSSC, 1996)

\begin{tabular}{llll}
\hline $\begin{array}{l}\text { Durasi } \\
\text { gerak }\end{array}$ & $\begin{array}{l}\text { Bangunan } \\
\text { baru }\end{array}$ & $\begin{array}{l}\text { Bangunan yang } \\
\text { telah ada dalam } \\
\text { kondisi sedang }\end{array}$ & $\begin{array}{l}\text { Bangunan } \\
\text { lama dalam } \\
\text { kondisi rusak }\end{array}$ \\
\hline $\begin{array}{l}\text { Singkat } \\
\text { Lama }\end{array}$ & $\begin{array}{l}\text { Tipe A } \\
\text { Tipe B }\end{array}$ & $\begin{array}{l}\text { Tipe B } \\
\text { Tipe C }\end{array}$ & $\begin{array}{l}\text { Tipe C } \\
\text { Tipe C }\end{array}$ \\
\hline
\end{tabular}

Karena fungsi gedung sebagai tempat tinggal, maka termasuk kategori resiko II (BSN, 2019) dan simpangan antar lantai yang diijinkan adalah:

dan

$$
\Delta_{a}=0,025 h_{s x}
$$

$$
\Delta=\delta_{i+1}-\delta_{i}
$$

dengan:

$h_{s x}$ : tinggi tingkat di bawah lantai $\mathrm{x}$

$\delta_{i} \quad$ : simpangan pada lantai ke-i

\section{HASIL DAN PEMBAHASAN}

\subsection{Pemodelan Struktur}

\subsubsection{Data Bangunan}

Bangunan yang ditinjau adalah rusunawa Itera lima lantai dengan sistem ganda dan berfungsi sebagai gedung tempat tinggal. Panjang, lebar, dan tinggi gedung berturut-turut adalah $63 \mathrm{~m} ; 19,2 \mathrm{~m}$; dan $15,7 \mathrm{~m}$. Tampak depan, belakang, dan samping bangunan diperlihatkan pada Gambar 3, 4, dan 5 . Denah arsitektur lantai dasar dan lantai 2-5 berturutturut diperllihatkan pada Gambar 6 dan 7. Denah struktur balok lantai 2-5, kolom, dan dinding geser lantai 1-5 berturut-turut diperlihatkan pada Gambar 8 sampai dengan 14 .

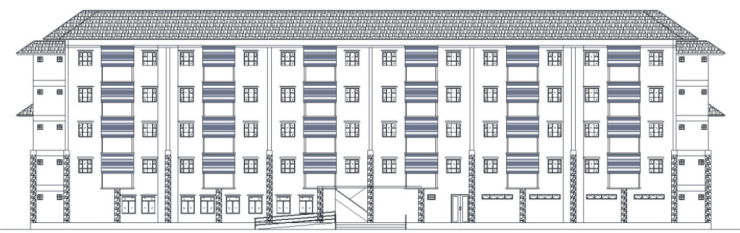

Gambar 3. Tampak depan bangunan (Satker PRRS, 2019)

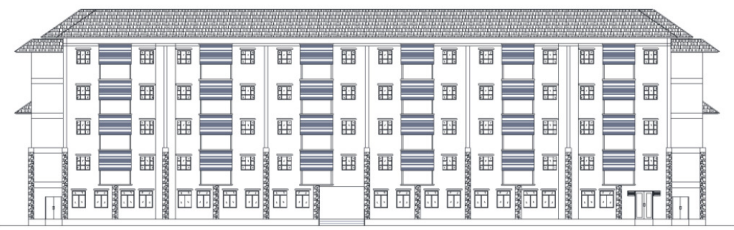

Gambar 4. Tampak belakang bangunan (Satker PRRS, 2019)

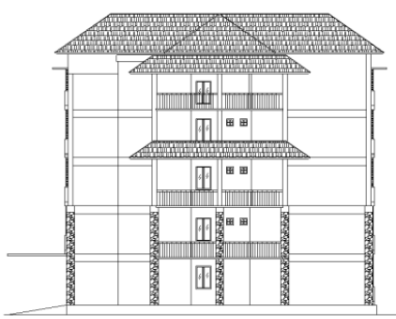

Gambar 5. Tampak samping bangunan (Satker PRRS, 2019)

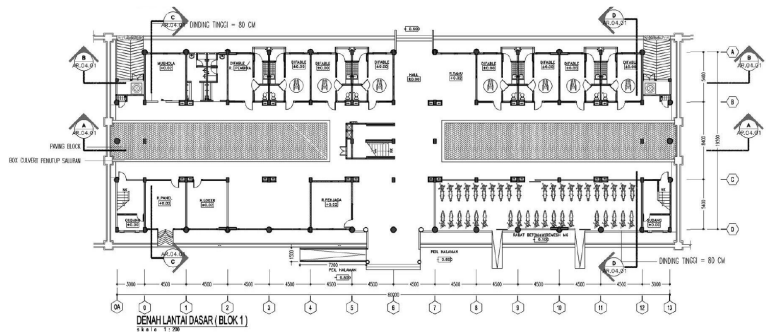

Gambar 6. Denah lantai 1 (Satker PRRS, 2019) 


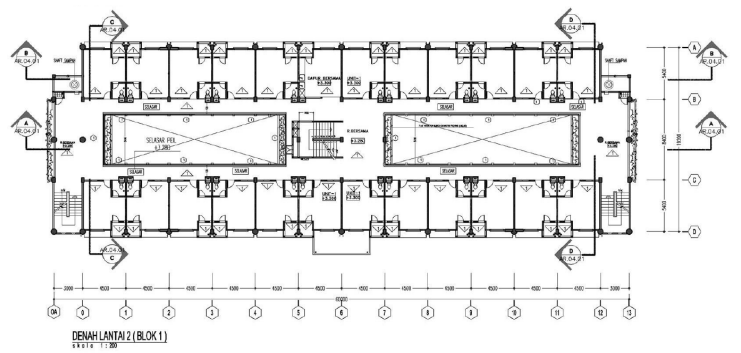

Gambar 7. Denah lantai 2, 3, 4, dan 5 (Satker PRRS, 2019)

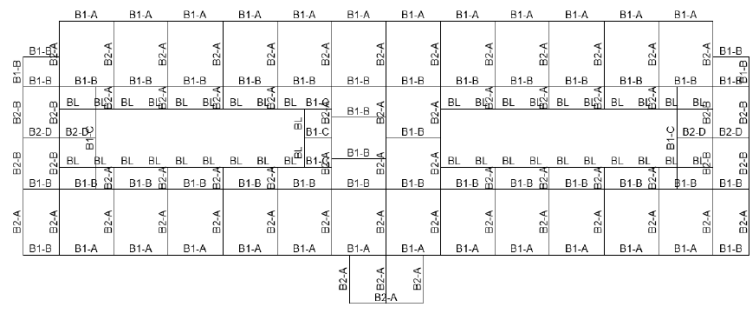

Gambar 8. Denah struktur balok lantai 2

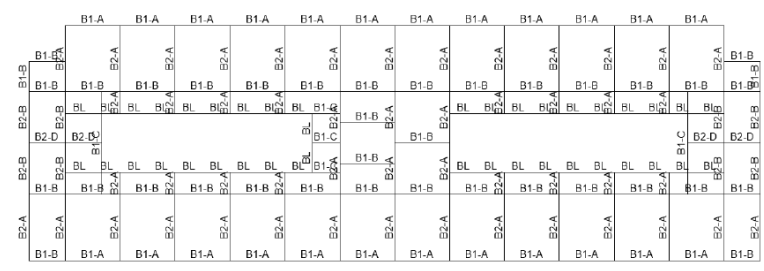

Gambar 9. Denah struktur balok lantai 3 dan 4

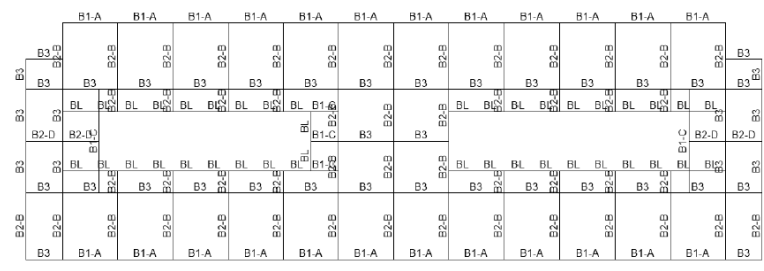

Gambar 10. Denah struktur balok lantai 5

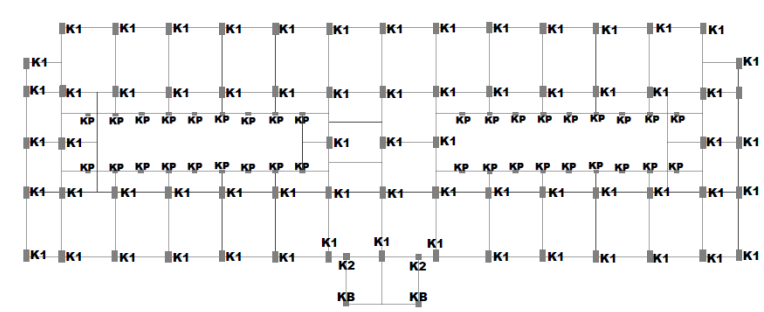

Gambar 11. Denah struktur kolom lantai 1 dan 2

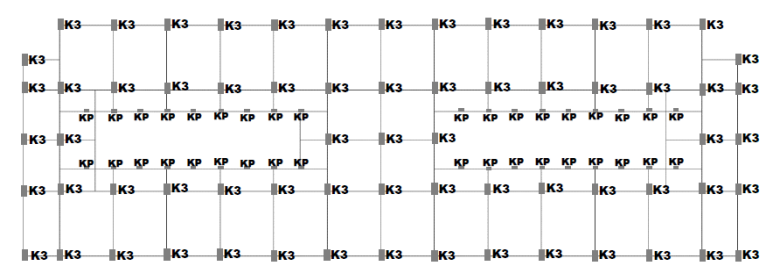

Gambar 12. Denah struktur kolom lantai 3 dan 4

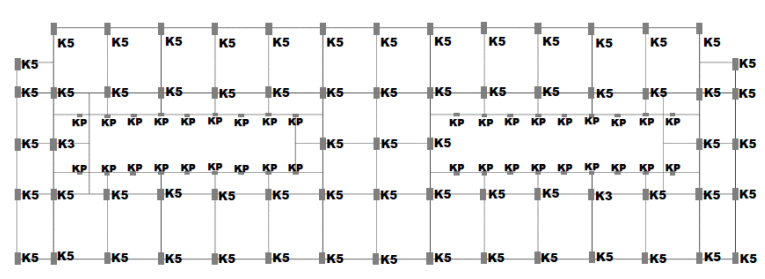

Gambar 13. Denah struktur kolom lantai 5

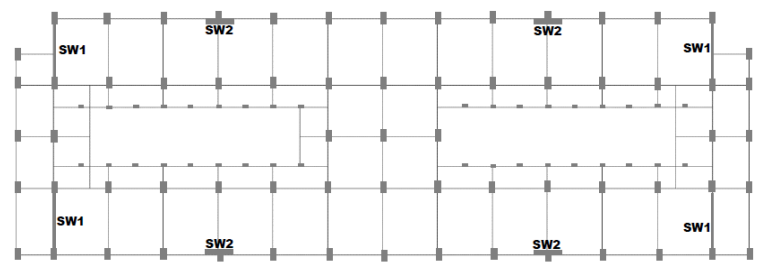

Gambar 14. Denah struktur dinding geser lantai 1-5

\subsubsection{Model Struktur}

Model-model struktur terdiri dari dua versi, yaitu:

1) struktur yang sesuai dengan rancangan dan bangunan yang didirikan (sistem ganda: rangka balok-kolom dan dinding geser);

2) struktur sistem rangka balok-kolom dan dinding geser $\mathrm{YZ}$ tanpa dinding geser $\mathrm{XZ}$;

3) struktur sistem rangka balok-kolom dan dinding geser XZ tanpa dinding geser $\mathrm{YZ}$;

4) stuktur yang hanya terdiri dari sistem rangka balok-kolom tanpa dinding geser.

Data material untuk semua model adalah: kuat tekan beton $\left(f_{c}^{\prime}\right)$, modulus elastisitas beton $\left(E_{c}\right)$, kuat leleh baja polos dan ulir $\left(f_{y}\right)$, kuat batas baja polos dan ulir $\left(f_{u}\right)$ berturut-turut adalah $30 \mathrm{MPa}$, $25743 \mathrm{MPa}, 240 \mathrm{MPa}, 414 \mathrm{MPa}, 390 \mathrm{MPa}$, dan 600 $\mathrm{MPa}$.

Beban yang ditahan oleh model pelat lantai adalah beban hidup dan beban mati masing-masing sebesar $250 \mathrm{~kg} / \mathrm{m}^{2}$ dan $114 \mathrm{~kg} / \mathrm{m}^{2}$. Beban hidup di atap dak beton adalah $100 \mathrm{~kg} / \mathrm{m}^{2}$. Beban pasangan dinding yang ditahan oleh balok adalah $775 \mathrm{~kg} / \mathrm{m}$. Pada balok keliling dan kolom lantai 5 terdapat beban atap. Bahan penutup atap adalah genteng yang menjadi beban mati adalah sebesar $20 \mathrm{~kg} / \mathrm{m}^{2}$; beban hidup atap adalah $100 \mathrm{~kg}$. Pemodelan atap diperlihatkan pada Gambar 15. Reaksi perletakan model atap menjadi beban pada model struktur bangunan pada Gambar 16.

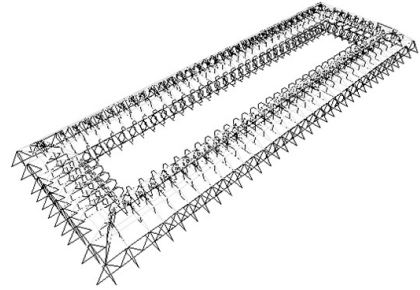

Gambar 15. Model rangka atap 


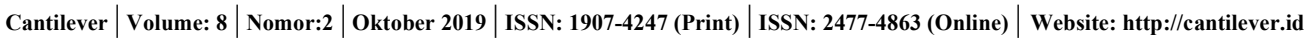

Nurjannah, dkk. / Kinerja Struktur Sistem Tunggal Dan Ganda Dengan Performance Based Design

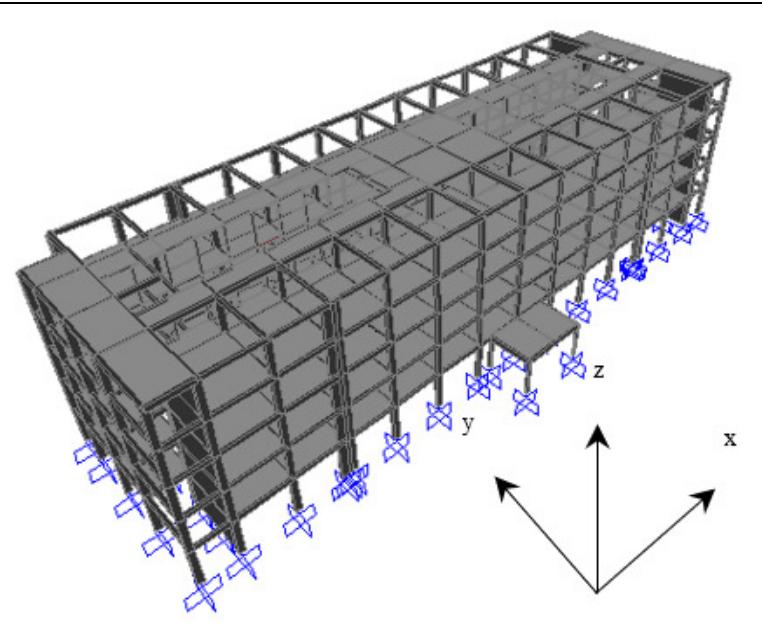

Gambar 16. Model struktur bangunan

Data dimensi dan tulangan kolom dan balok adalah seperti yang diperlihatkan pada Tabel 4 dan Tabel 5. Tebal pelat adalah $130 \mathrm{~mm}$ dengan tulangan dua arah D10-150. Dinding geser setebal $250 \mathrm{~mm}$ dengan tulangan longitudinal dan transversal masing-masing adalah D13-100 dan D13-150. Setiap lantai diatur sebagai diafragma sehingga menjadi kumpulan-kumpulan massa.

Tabel 4. Data kolom

\begin{tabular}{llll}
\hline \multirow{2}{*}{ Tipe kolom } & Dimensi & \multicolumn{2}{c}{ Tulangan } \\
\cline { 2 - 4 } & $(\mathrm{mm})$ & Longitudinal & Sengkang \\
\hline K1 & $350 \times 500$ & $12 \mathrm{D} 16$ & D10-100 \\
K2 & $300 \times 300$ & $8 \mathrm{D} 16$ & D10-100 \\
K3 & $350 \times 500$ & $8 \mathrm{D} 16$ & D10-100 \\
K5 & $350 \times 500$ & 8 D16 & D10-100 \\
KB & $200 \times 300$ & 6 D16 & D10-100 \\
KP & $150 \times 200$ & $4 \phi 10$ & $\phi 8-150$ \\
\hline
\end{tabular}

Tabel 5. Data balok

\begin{tabular}{lllll}
\hline \multirow{2}{*}{ Tipe balok } & \multicolumn{3}{c}{ Dimensi } & \multicolumn{3}{c}{ Tulangan } \\
\cline { 2 - 5 } & $(\mathrm{mm})$ & Atas & Bawah & Sengkang \\
\hline B1-A & $200 \times 400$ & $5 \mathrm{D} 16$ & $3 \mathrm{D} 16$ & D10-100 \\
B1-B & $200 \times 400$ & $5 \mathrm{D} 16$ & $3 \mathrm{D} 16$ & D10-100 \\
B1-C & $200 \times 400$ & $3 \mathrm{D} 16$ & $3 \mathrm{D} 16$ & D10-100 \\
B2-A & $250 \times 450$ & $4 \mathrm{D} 16$ & $3 \mathrm{D} 16$ & D10-100 \\
B2-B & $250 \times 450$ & $4 \mathrm{D} 16$ & $2 \mathrm{D} 16$ & D10-100 \\
B2-D & $250 \times 450$ & 3 D16 & 3 D16 & D10-100 \\
B3 & $250 \times 400$ & $4 \mathrm{D} 16$ & $2 \mathrm{D} 16$ & D10-175 \\
BL & $150 \times 200$ & $2 \mathrm{D} 10$ & $2 \mathrm{D} 8$ & D10-175 \\
\hline
\end{tabular}

Sendi plastis berada pada setiap ujung balok dan kolom serta sisi bawah dinding geser. Properti sendi plastis pada balok, kolom, dan dinding geser adalah sesuai dengan dimensi penampang, data material, dan detil tulangan.

\subsubsection{Spektra Respons}

Beban gempa dimasukkan ke dalam pemodelan berupa spektra respons sesuai lokasi bangunan yang ditinjau dan jenis tanah, yaitu di Kecamatan Jati Agung, Kabupaten Lampung Selatan, jenis tanah sedang, seperti yang diperlihatkan pada Gambar 17. Periode fundamental bangunan diperoleh dengan pendekatan dari persamaan (9):

$$
T=C_{t} h_{n}^{x}
$$

dengan:

$T$ : periode fundamental (detik)

$h_{n}^{x}$ : tinggi total struktur (meter)

$C_{t} \quad$ : koefisien pengali berdasarkan tipe struktur

$x \quad$ : koefisien pangkat berdasarkan tipe struktur

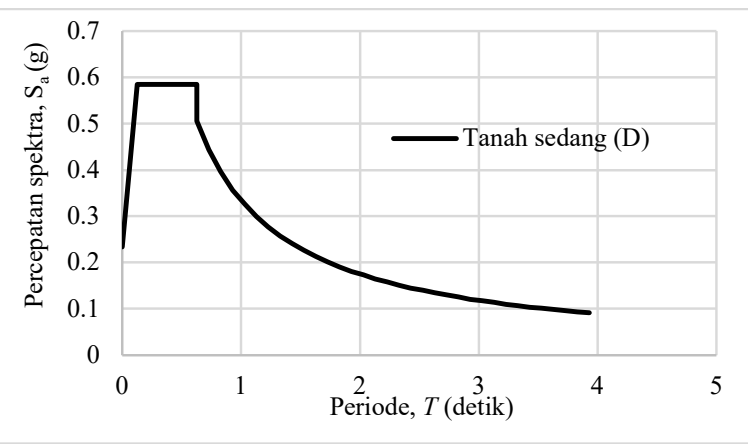

Gambar 17. Spektra respons (Puskim, 2011)

Karena struktur berupa rangka beton pemikul momen, maka $C_{t}$ dan $x$ berturut-turut adalah 0,0466 dan 0,9 . Tinggi gedung dari dasar ke atap adalah 15,7 meter, maka diperoleh periode fundamental struktur adalah 0,555 detik dan digunakan sebagai salah satu input parameter kegempaan dalam pemodelan. Input parameter-parameter kegempaan lainnya adalah koefisien modifikasi respons (R), faktor kuat lebih $\left(\Omega_{o}\right)$, faktor amplifikasi defleksi $\left(C_{d}\right)$, dan faktor keutamaan (I) sebesar $8 ; 3 ; 5,5$; dan 1. Koefisien seismik dalam pemodelan adalah parameter percepatan spektra respons Maximum Considered Earthquake (MCE) dari peta gempa pada periode pendek redaman $5 \%\left(S_{S}\right)$ dan parameter percepatan spektra respons MCE dari peta gempa pada periode 1 detik redaman 5\% $\left(S_{1}\right)$ berturut-turut adalah 0,714 dan 0,31. Kelas situs adalah D (tanah sedang), sehingga koefisien situs pada periode pendek 0,2 detik $\left(F_{a}\right)$ dan koefisien situs pada periode panjang $\left(F_{v}\right)$ adalah 1,2288 dan 1,78 , sehingga parameter percepatan spektra respons pada periode pendek redaman $5 \%\left(S_{D S}\right)$ dan parameter percepatan spektra respons pada periode 1 detik redaman $5 \%\left(S_{D 1}\right)$ adalah 0,5849 dan 0,3679 (BSN, 2019).

Tipe perilaku struktur termasuk kategori B, yaitu mampu mendisipasi energi dengan kemampuan sedang (ASCE, 2000). 


\section{3}

\section{.2 Kurva Kapasitas dan Tingkat Kinerja}

Pemodelan empat macam sistem struktur menghasilkan kurva-kurva kapasitas seperti yang diperlihatkan pada Gambar 18 dan 19. Akibat gempa yang searah dengan sumbu $\mathrm{X}$ bangunan, perpindahan maksimum terkecil terjadi pada model yang menggunakan sistem ganda karena memiliki kekakuan besar dari dinding-dinding geser, sehingga model ini merupakan yang terbaik dalam menahan beban gempa searah sumbu X bangunan. Model struktur rangka tanpa dinding geser di arah $\mathrm{XZ}$ (sejajar dengan arah gempa $X$ ) mengalami perpindahan maksimum lebih kecil daripada model struktur rangka tanpa dinding geser di arah $\mathrm{YZ}$ (tegak lurus arah gempa $\mathrm{X}$ ) karena hanya mampu menahan gaya geser dasar sebesar 14228,52 kN dibandingkan 16296,89 kN. Model tanpa dinding geser YZ mencapai gaya geser dasar maksimum terbesar dibandingkan dengan model-model lain karena kekakuan yang berkurang akibat tidak adanya dinding geser YZ memungkinkan sistem struktur mengalami perpindahan cukup besar dibandingkan dengan sistem ganda. Rangka tanpa dinding geser merupakan sistem paling lemah karena mengalami perpindahan terbesar dengan gaya geser dasar maksimum terkecil, yaitu 13967,95 kN. Data selengkapnya ditampilkan pada Tabel 6.

Pada pembebanan gempa di arah sumbu Y, perpindahan terkecil dan gaya geser dasar terbesar terjadi pada sistem struktur ganda, sehingga merupakan sistem struktur paling baik dalam menahan beban gempa karena memiliki dindingdinding geser yang memberikan kekuatan dan kekakuan tambahan. Rangka tanpa dinding geser di arah sumbu XZ (tegak lurus arah gempa Y) hanya mampu menahan gaya geser dasar sebesar 16359,22 $\mathrm{kN}$, dibandingkan dengan sistem ganda $(18478,79)$. Perpindahan maksimumnya lebih kecil daripada rangka tanpa dinding geser searah sumbu YZ (sejajar dengan arah gempa Y). Model rangka tanpa dinding geser adalah sistem yang terlemah dalam menahan gaya gempa di arah sumbu Y karena memiliki gaya geser dasar maksimum yang paling kecil, seperti yang diperlihatkan dalam Tabel 7.

Kurva-kurva kapasitas pada Gambar 18 dan 19 diubah menjadi spektrum-spektrum kapasitas pada Gambar 20 dan 21 dengan persamaan (1) sampai dengan (4). Perilaku semua model struktur dalam bentuk spektrum kapasitas adalah identik dengan bentuk kurva kapasitas. Dengan demikian, model dengan sistem struktur ganda adalah yang paling kuat dalam menahan beban gempa pada arah sumbu $\mathrm{X}$ dan $\mathrm{Y}$, sedangkan model dengan struktur rangka tanpa dinding geser adalah yang paling lemah dalam menahan beban gempa pada arah sumbu X dan Y.

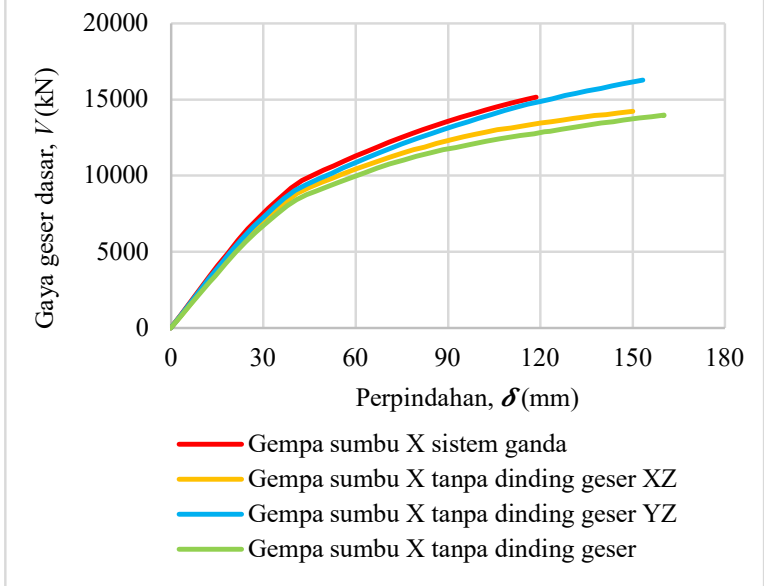

Gambar 18. Kurva kapasitas struktur arah gempa X

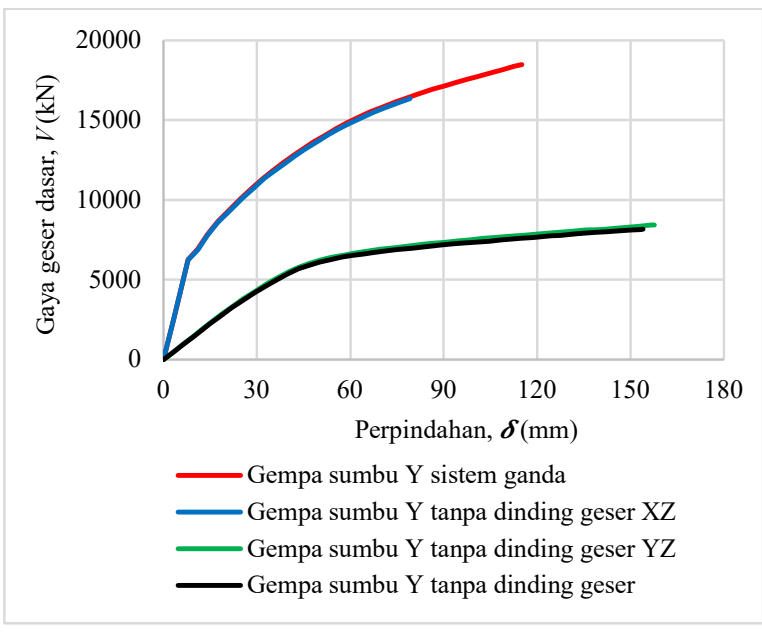

Gambar 19. Kurva kapasitas struktur arah gempa Y

Tabel 6. Gaya geser dasar dan perpindahan maksimum akibat gempa searah sumbu X

\begin{tabular}{lcc}
\hline Sistem struktur & $\begin{array}{l}\text { Gaya geser } \\
\text { dasar } \\
(\mathrm{kN})\end{array}$ & $\begin{array}{l}\text { Perpindah- } \\
\text { an } \\
(\mathrm{mm})\end{array}$ \\
\hline Ganda & 15165,63 & 118,62 \\
Rangka tanpa dinding geser & 14228,52 & 150,10 \\
XZ & & \\
Rangka tanpa dinding geser & 16296,89 & 153,28 \\
YZ & 13967,95 & 160,21 \\
\hline Rangka tanpa dinding geser & & \\
\hline
\end{tabular}

Tabel 7. Gaya geser dasar dan perpindahan maksimum akibat gempa searah sumbu Y

\begin{tabular}{lcr}
\hline Sistem struktur & $\begin{array}{l}\text { Gaya geser } \\
\text { dasar } \\
(\mathrm{kN})\end{array}$ & $\begin{array}{l}\text { Perpindah- } \\
\text { an } \\
(\mathrm{mm})\end{array}$ \\
\hline Ganda & 18478,79 & 115,10 \\
Rangka tanpa dinding geser & 16359,22 & 79,16 \\
XZ & & \\
Rangka tanpa dinding geser & 8426,09 & 157,65 \\
YZ & 8157,64 & 154,09 \\
Rangka tanpa dinding geser & & \\
\hline
\end{tabular}

78 Attribution-NonCommercial 4.0 International. Some rights reserved 


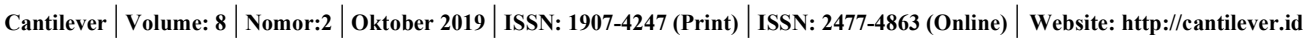
Nurjannah, dkk. / Kinerja Struktur Sistem Tunggal Dan Ganda Dengan Performance Based Design

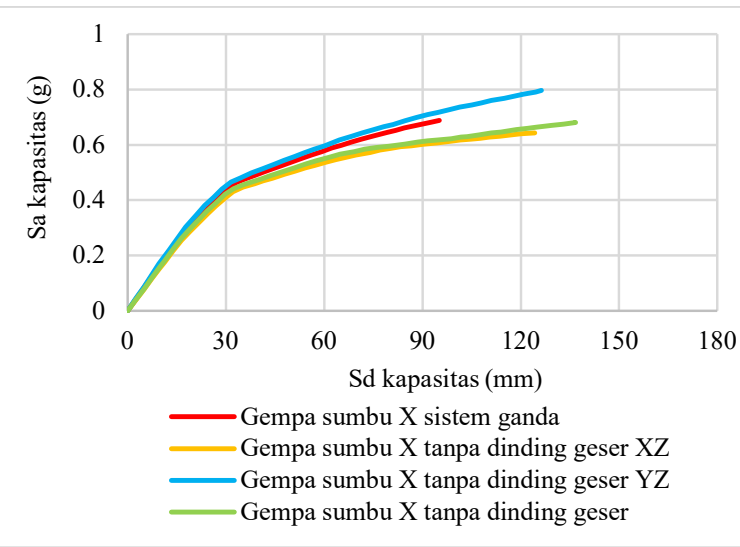

Gambar 20. Spektrum kapasitas struktur arah gempa X

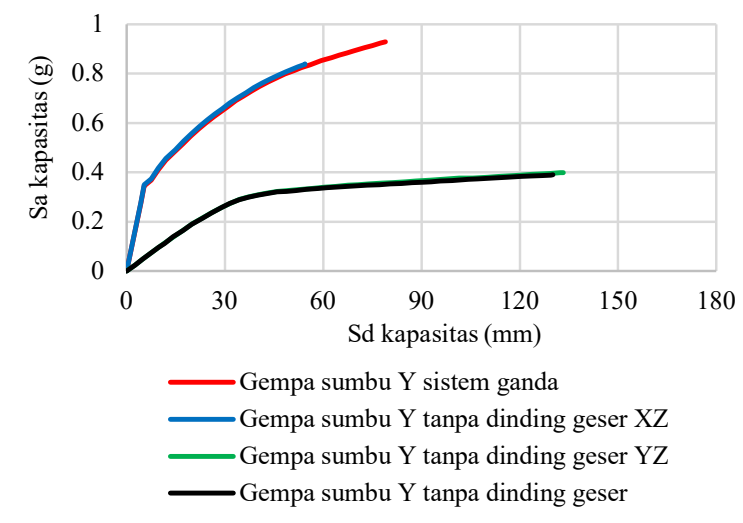

Gambar 21. Spektrum kapasitas struktur arah gempa Y

Analisis dengan persamaan (5) s/d Persamaan (7) dan penentuan lokasi pertemuan spektrum-spektrum kapasitas dengan spektrum-spektrum keperluan menghasilkan titik-titik kinerja keempat model struktur seperti yang diperlihatkan pada Tabel 8, Tabel 9, Tabel 10 dan Tabel 11.

Tabel 8. Koordinat titik-titik kinerja model struktur dengan beban gempa arah sumbu X pada kurva kapasitas

\begin{tabular}{|c|c|c|}
\hline Sistem struktur & $\begin{array}{l}V \\
(\mathrm{kN})\end{array}$ & $\begin{array}{l}\delta \\
(\mathrm{mm})\end{array}$ \\
\hline Ganda & 9969,34 & 45,49 \\
\hline Rangka tanpa dinding geser $\mathrm{XZ}$ & 9555,82 & 48,92 \\
\hline Rangka tanpa dinding geser $\mathrm{YZ}$ & 9362,99 & 43,45 \\
\hline Rangka tanpa dinding geser & 8957,51 & 46,77 \\
\hline
\end{tabular}

Keterangan:

$V$ : gaya geser dasar $(\mathrm{kN}) ; \delta$ : perpindahan $(\mathrm{mm})$

Tabel 9. Koordinat titik-titik kinerja dan tingkat kinerja model struktur dengan beban gempa arah sumbu Y pada kurva kapasitas

\begin{tabular}{lcc}
\hline Sistem struktur & $\begin{array}{l}l \\
(\mathrm{kN})\end{array}$ & $\begin{array}{l}\delta \\
(\mathrm{mm})\end{array}$ \\
\hline Ganda & 7942,72 & 14,54 \\
Rangka tanpa dinding geser XZ & 7821,05 & 14,21 \\
Rangka tanpa dinding geser YZ & 6546,83 & 57,67 \\
Rangka tanpa dinding geser & 6408,34 & 57,52 \\
\hline
\end{tabular}

Tabel 10. Koordinat titik-titik kinerja model struktur dengan beban gempa arah sumbu $\mathrm{X}$ pada spektrum kapasitas dan keperluan

\begin{tabular}{|c|c|c|c|c|}
\hline Sistem struktur & $\begin{array}{l}S_{a} \\
(\mathrm{~g})\end{array}$ & $\begin{array}{l}S_{d} \\
(\mathrm{~mm})\end{array}$ & $\begin{array}{l}T_{\text {eff }} \\
\text { (detik) }\end{array}$ & $\beta_{\text {eff }}$ \\
\hline Ganda & 0,475 & 35,454 & 0,548 & 0,114 \\
\hline $\begin{array}{l}\text { Rangka tanpa dinding } \\
\text { geser XZ }\end{array}$ & 0,459 & 38,665 & 0,582 & 0,126 \\
\hline $\begin{array}{l}\text { Rangka tanpa dinding } \\
\text { geser YZ } \\
\text { Rangka tanpa dinding }\end{array}$ & 0,480 & 34,136 & 0,535 & 0,110 \\
\hline geser & 0,463 & 37,322 & 0,570 & 0,123 \\
\hline \multicolumn{5}{|l|}{ Keterangan: } \\
\hline $\begin{array}{cll}S_{a}: & \text { percep } \\
S_{d}: & \text { perpin } \\
T_{\text {eff }}: & \text { period } \\
\beta_{\text {eff }}: & \text { redam }\end{array}$ & $\begin{array}{l}\text { ektra; } \\
\text { spektra; } \\
\text { if; } \\
\text { ous efek }\end{array}$ & & & \\
\hline
\end{tabular}

Tabel 11. Koordinat titik-titik kinerja model struktur dengan beban gempa arah sumbu Y pada spektrum kapasitas dan keperluan

\begin{tabular}{lllll}
\hline Sistem struktur & $\begin{array}{l}S_{a} \\
(\mathrm{~g})\end{array}$ & $\begin{array}{l}S_{d} \\
(\mathrm{~mm})\end{array}$ & $\begin{array}{l}T_{\text {eff }} \\
(\mathrm{detik})\end{array}$ & $\beta_{\text {eff }}$ \\
\hline $\begin{array}{l}\text { Ganda } \\
\text { Rangka tanpa dinding } \\
\text { geser XZ }\end{array}$ & 0,416 & 9,967 & 0,310 & 0,168 \\
$\begin{array}{l}\text { Rangka tanpa dinding } \\
\text { geser YZ }\end{array}$ & 0,418 & 9,740 & 0,306 & 0,167 \\
$\begin{array}{l}\text { Rangka tanpa dinding } \\
\text { geser }\end{array}$ & 0,322 & 46,173 & 0,759 & 0,144 \\
\hline
\end{tabular}

Tingkat kinerja setiap model struktur pada saat titik kinerja tercapai akibat beban gempa pada arah sumbu X dan Y berturut-turut diperlihatkan pada Tabel 12 dan Tabel 13. Akibat beban gempa pada arah sumbu $X$, sistem struktur ganda dan rangka tanpa dinding geser mencapai tingkat kinerja Collapse, sedangkan rangka tanpa dinding geser XZ (sejajar arah gempa $X$ ) mencapai tingkat kinerja yang lebih jauh daripada rangka tanpa dinding geser YZ (tegak lurus arah gempa X) karena mencapai tingkat kinerja Reduced strength yang lebih jauh daripada Immediate Occupancy. Lokasi sendi plastis yang menjadi acuan tingkat kinerja terdapat pada kolom KB.

Akibat beban gempa searah sumbu Y, sistem struktur ganda dan rangka tanpa dinding geser XZ (tegak lurus arah gempa Y) mencapai tingkat kinerja leleh, sedangkan rangka tanpa dinding geser YZ (sejajar arah gempa $\mathrm{Y}$ ) dan rangka tanpa dinding geser mencapai tingkat kinerja yang lebih jauh, yaitu Zero strength. Lokasi sendi plastis yang menjadi acuan tingkat kinerja terdapat pada balok B2-A dan B2-B, kolom KB, serta dinding geser YZ. 
Tabel 12. Tingkat kinerja model struktur akibat gempa pada arah sumbu $X$

\begin{tabular}{|c|c|c|c|}
\hline Sistem struktur & $\begin{array}{l}\text { Tingkat } \\
\text { kinerja }\end{array}$ & Komponen & Lokasi \\
\hline Ganda & Collapse & Kolom KB & $\begin{array}{l}\text { Lt. 1, } \\
\text { depan }\end{array}$ \\
\hline $\begin{array}{l}\text { Rangka tanpa } \\
\text { dinding geser XZ }\end{array}$ & $\begin{array}{l}\text { Reduced } \\
\text { strength }\end{array}$ & Kolom KB & $\begin{array}{l}\text { Lt. } 1 \text {, } \\
\text { depan }\end{array}$ \\
\hline $\begin{array}{l}\text { Rangka tanpa } \\
\text { dinding geser YZ }\end{array}$ & $\begin{array}{l}\text { Immediate } \\
\text { Occupancy }\end{array}$ & Kolom KB & $\begin{array}{l}\text { Lt. 1, } \\
\text { depan }\end{array}$ \\
\hline $\begin{array}{l}\text { Rangka tanpa } \\
\text { dinding geser }\end{array}$ & Collapse & Kolom KB & $\begin{array}{l}\text { Lt. 1, } \\
\text { depan }\end{array}$ \\
\hline
\end{tabular}

Tabel 13. Tingkat kinerja model struktur akibat gempa pada arah sumbu Y

\begin{tabular}{|c|c|c|c|}
\hline Sistem struktur & $\begin{array}{l}\text { Tingkat } \\
\text { kinerja }\end{array}$ & Komponen & Lokasi \\
\hline Ganda & Leleh & $\begin{array}{l}\text { Balok B2-A, } \\
\text { B2-B, dan } \\
\text { dinding geser } \\
\text { YZ }\end{array}$ & Lt. 1-6 \\
\hline $\begin{array}{l}\text { Rangka tanpa } \\
\quad \text { dinding geser } \mathrm{XZ}\end{array}$ & Leleh & $\begin{array}{l}\text { Dinding geser } \\
\text { YZ }\end{array}$ & $\begin{array}{l}\text { Lt. 1, } \\
\text { tengah }\end{array}$ \\
\hline $\begin{array}{l}\text { Rangka tanpa } \\
\text { dinding geser } Y Z\end{array}$ & $\begin{array}{l}\text { Zero } \\
\text { strength }\end{array}$ & Kolom KB & $\begin{array}{l}\text { Lt. } 1 \text {, } \\
\text { depan }\end{array}$ \\
\hline $\begin{array}{l}\text { Rangka tanpa } \\
\text { dinding geser }\end{array}$ & $\begin{array}{l}\text { Zero } \\
\text { strength }\end{array}$ & Kolom KB & $\begin{array}{l}\text { Lt. 1, } \\
\text { depan }\end{array}$ \\
\hline
\end{tabular}

\subsection{Perpindahan Antar Lantai}

Perpindahan antar lantai pada saat titik kinerja tercapai diperlihatkan pada Tabel $14 \mathrm{~s} / \mathrm{d}$ Tabel 21. Terlihat bahwa semua perpindahan antar lantai $(\Delta)$ tidak sampai melampaui perpindahan ijin $\left(\Delta_{a}\right)$, sehingga dikategorikan aman.

Tabel 14. Perpindahan antar lantai sistem ganda, gempa arah sumbu X

\begin{tabular}{|c|c|c|c|c|c|}
\hline Tingkat & $\begin{array}{l}\mathrm{h}_{\mathrm{sx}} \\
(\mathrm{mm})\end{array}$ & $\begin{array}{l}\Delta_{\mathrm{a}} \\
(\mathrm{mm})\end{array}$ & $\begin{array}{l}\delta \\
(\mathrm{mm})\end{array}$ & $\begin{array}{l}\Delta \\
(\mathrm{mm})\end{array}$ & $\begin{array}{l}\Delta_{\mathrm{a}}>\Delta \\
(\mathrm{mm})\end{array}$ \\
\hline Atap & 3000 & 75,0 & 118,33 & 6,42 & Ya; aman \\
\hline 5 & 3000 & 75,0 & 111,91 & 12,80 & Ya; aman \\
\hline 4 & 3000 & 75,0 & 99,11 & 23,67 & Ya; aman \\
\hline 3 & 3000 & 75,0 & 75,45 & 33,43 & Ya; aman \\
\hline 2 & 3300 & 82,5 & 42,02 & 42,02 & Ya; aman \\
\hline
\end{tabular}

Tabel 15. Perpindahan antar lantai sistem ganda, gempa arah sumbu Y

\begin{tabular}{lccccc}
\hline Tingkat & $\begin{array}{l}\mathrm{h}_{\mathrm{sx}} \\
(\mathrm{mm})\end{array}$ & $\begin{array}{l}\Delta_{\mathrm{a}} \\
(\mathrm{mm})\end{array}$ & \multicolumn{1}{l}{$\delta$} & \multicolumn{1}{c}{$\begin{array}{l}(\mathrm{mm}) \\
(\mathrm{mm})\end{array}$} & $\begin{array}{l}\Delta_{\mathrm{a}}>\Delta \\
(\mathrm{mm})\end{array}$ \\
\hline Atap & 3000 & 75,0 & 115,10 & 22,51 & Ya; aman \\
5 & 3000 & 75,0 & 92,60 & 22,88 & Ya; aman \\
4 & 3000 & 75,0 & 69,71 & 23,16 & Ya; aman \\
3 & 3000 & 75,0 & 46,55 & 23,01 & Ya; aman \\
2 & 3300 & 82,5 & 23,54 & 23,54 & Ya; aman \\
\hline
\end{tabular}

Tabel 16. Perpindahan antar lantai sistem rangka tanpa dinding geser XZ, gempa arah sumbu X

\begin{tabular}{lrrrrl}
\hline Tingkat & $\begin{array}{l}\mathrm{h}_{\mathrm{sx}} \\
(\mathrm{mm})\end{array}$ & $\begin{array}{l}\Delta_{\mathrm{a}} \\
(\mathrm{mm})\end{array}$ & \multicolumn{1}{l}{$\begin{array}{l}(\mathrm{mm}) \\
(\mathrm{mm})\end{array}$} & $\begin{array}{l}\Delta \\
(\mathrm{mm})\end{array}$ \\
\hline Atap & 3000 & 75,0 & 149,64 & 5,46 & Ya; aman \\
5 & 3000 & 75,0 & 144,18 & 11,73 & Ya; aman \\
4 & 3000 & 75,0 & 132,45 & 27,79 & Ya; aman \\
3 & 3000 & 75,0 & 104,65 & 44,39 & Ya; aman \\
2 & 3300 & 82,5 & 60,26 & 60,26 & Ya; aman \\
\hline
\end{tabular}

Tabel 17. Perpindahan antar lantai sistem rangka tanpa dinding geser XZ, gempa arah sumbu Y

\begin{tabular}{lccccl}
\hline Tingkat & $\begin{array}{l}\mathrm{h}_{\mathrm{sx}} \\
(\mathrm{mm})\end{array}$ & $\begin{array}{l}\Delta_{\mathrm{a}} \\
(\mathrm{mm})\end{array}$ & $\begin{array}{l}\delta \\
(\mathrm{mm})\end{array}$ & $\begin{array}{l}\Delta \\
(\mathrm{mm})\end{array}$ & $\begin{array}{l}\Delta_{\mathrm{a}}>\Delta \\
(\mathrm{mm})\end{array}$ \\
\hline Atap & 3000 & 75,0 & 79,16 & 15,41 & Ya; aman \\
5 & 3000 & 75,0 & 63,75 & 15,75 & Ya; aman \\
4 & 3000 & 75,0 & 48,00 & 16,01 & Ya; aman \\
3 & 3000 & 75,0 & 31,99 & 15,91 & Ya; aman \\
2 & 3300 & 82,5 & 16,08 & 16,08 & Ya; aman \\
\hline
\end{tabular}

Tabel 18. Perpindahan antar lantai sistem rangka tanpa dinding geser YZ, gempa arah sumbu $\mathrm{X}$

\begin{tabular}{lrrrrl}
\hline Tingkat & $\begin{array}{l}\mathrm{h}_{\mathrm{sx}} \\
(\mathrm{mm})\end{array}$ & $\begin{array}{l}\Delta_{\mathrm{a}} \\
(\mathrm{mm})\end{array}$ & $\begin{array}{l}\delta \\
(\mathrm{mm})\end{array}$ & \multicolumn{1}{c}{$\begin{array}{l}\Delta \\
(\mathrm{mm})\end{array}$} & $\begin{array}{l}\Delta_{\mathrm{a}}>\Delta \\
(\mathrm{mm})\end{array}$ \\
\hline Atap & 3000 & 75,0 & 155,43 & 7,42 & Ya; aman \\
5 & 3000 & 75,0 & 148,01 & 15,64 & Ya; aman \\
4 & 3000 & 75,0 & 132,37 & 31,29 & Ya; aman \\
3 & 3000 & 75,0 & 101,08 & 44,35 & Ya; aman \\
2 & 3300 & 82,5 & 56,72 & 56,72 & Ya; aman \\
\hline
\end{tabular}

Tabel 19. Perpindahan antar lantai sistem rangka tanpa dinding geser YZ, gempa arah sumbu Y

\begin{tabular}{lcrrrl}
\hline Tingkat & $\begin{array}{l}\mathrm{h}_{\mathrm{sx}} \\
(\mathrm{mm})\end{array}$ & $\begin{array}{l}\Delta_{\mathrm{a}} \\
(\mathrm{mm})\end{array}$ & \multicolumn{1}{l}{$\delta$} & \multicolumn{1}{c}{$\begin{array}{l}\Delta \\
(\mathrm{mm})\end{array}$} & $\begin{array}{l}\Delta_{\mathrm{a}}>\Delta \\
(\mathrm{mm})\end{array}$ \\
\hline Atap & 3000 & 75,0 & 157,65 & 4,49 & Ya; aman \\
5 & 3000 & 75,0 & 153,15 & 9,93 & Ya; aman \\
4 & 3000 & 75,0 & 143,23 & 27,27 & Ya; aman \\
3 & 3000 & 75,0 & 115,96 & 44,31 & Ya; aman \\
2 & 3300 & 82,5 & 71,65 & 71,65 & Ya; aman \\
\hline
\end{tabular}

Tabel 20. Perpindahan antar lantai sistem rangka tanpa dinding geser, gempa arah sumbu $\mathrm{X}$

\begin{tabular}{lcrlrl}
\hline Tingkat & $\begin{array}{l}\mathrm{h}_{\mathrm{sx}} \\
(\mathrm{mm})\end{array}$ & $\begin{array}{l}\Delta_{\mathrm{a}} \\
(\mathrm{mm})\end{array}$ & \multicolumn{1}{l}{$\delta$} & \multicolumn{1}{c}{$\begin{array}{l}\Delta \\
(\mathrm{mm})\end{array}$} & $\begin{array}{l}\Delta_{\mathrm{a}}>\Delta \\
(\mathrm{mm})\end{array}$ \\
\hline Atap & 3000 & 75,0 & 162,02 & 5,27 & Ya; aman \\
5 & 3000 & 75,0 & 156,74 & 10,79 & Ya; aman \\
4 & 3000 & 75,0 & 145,95 & 29,17 & Ya; aman \\
3 & 3000 & 75,0 & 116,78 & 44,54 & Ya; aman \\
2 & 3300 & 82,5 & 72,24 & 72,24 & Ya; aman \\
\hline
\end{tabular}

Tabel 21. Perpindahan antar lantai sistem rangka tanpa dinding geser, gempa arah sumbu Y

\begin{tabular}{lcrrrl}
\hline Tingkat & $\begin{array}{l}\mathrm{h}_{\mathrm{sx}} \\
(\mathrm{mm})\end{array}$ & $\begin{array}{l}\Delta_{\mathrm{a}} \\
(\mathrm{mm})\end{array}$ & $\begin{array}{l}\delta \\
(\mathrm{mm})\end{array}$ & \multicolumn{1}{c}{$\begin{array}{l}\Delta \\
(\mathrm{mm})\end{array}$} & $\begin{array}{l}\Delta_{\mathrm{a}}>\Delta \\
(\mathrm{mm})\end{array}$ \\
\hline Atap & 3000 & 75,0 & 154,09 & 4,33 & Ya; aman \\
5 & 3000 & 75,0 & 149,75 & 9,31 & Ya; aman \\
4 & 3000 & 75,0 & 140,45 & 25,57 & Ya; aman \\
3 & 3000 & 75,0 & 114,88 & 38,14 & Ya; aman \\
2 & 3300 & 82,5 & 76,74 & 76,74 & Ya; aman \\
\hline
\end{tabular}

\section{KESIMPULAN}

Analisis hasil pemodelan empat variasi struktur, yaitu sistem ganda, rangka tanpa dinding geser XZ, rangka tanpa dinding geser $\mathrm{YZ}$, dan rangka tanpa dinding geser menghasilkan beberapa kesimpulan sebagai berikut:

1. Kurva-kurva kapasitas hasil analisis pushover memperlihatkan bahwa model struktur sistem ganda mengalami perpindahan lateral maksimum terkecil akibat beban gempa searah sumbu $\mathrm{X}$ karena memiliki kekakuan terbesar dibandingkan model-model lain, serta memiliki gaya geser dasar maksimum terbesar akibat beban gempa searah sumbu Y. 


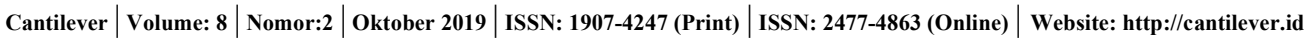

Nurjannah, dkk. / Kinerja Struktur Sistem Tunggal Dan Ganda Dengan Performance Based Design

2. Model rangka tanpa dinding geser merupakan sistem struktur paling lemah karena mengalami perpindahan lateral maksimum terbesar akibat beban gempa searah sumbu $\mathrm{X}$ dan gaya geser dasar terkecil akibat beban gempa searah sumbu Y.

3. Pada pembebanan gempa searah sumbu $X$, sistem ganda dan rangka tanpa dinding geser mencapai tingkat kinerja Collapse, sedangkan rangka tanpa dinding geser XZ dan YZ masingmasing mencapai tingkat kinerja Reduced strength dan Immediate Occupancy.

4. Pada pembebanan gempa searah sumbu $Y$, sistem ganda dan rangka tanpa dinding geser XZ mencapai tingkat kinerja leleh, sedangkan rangka tanpa dinding geser $\mathrm{YZ}$ dan rangka tanpa dinding geser mencapai tingkat kinerja Zero strength.

5. Pada saat titik kinerja tercapai dan di bawah beban gempa searah sumbu $\mathrm{X}$ dan $\mathrm{Y}$, sistem ganda menunjukkan kinerja terbaik dengan kemampuan menahan gaya geser dasar terbesar, sedangkan sistem rangka tanpa dinding geser memiliki kinerja terendah.

6. Analisis perpindahan lateral antar tingkat lantai akibat beban gempa arah sumbu $\mathrm{X}$ dan $\mathrm{Y}$ memperlihatkan bahwa semua sistem struktur masih dalam batas aman.

\section{REFERENSI}

American Society of Civil Engineers (ASCE) for Federal Emergency Management Agency. (2000). FEMA 356: Prestandard and Commentary for the Seismic Rehabilitation of Buildings, November 2000, Washington D.C.

Badan Standardisasi Nasional (BSN). (2019). SNI 1726:2019 Tata Cara Perencanaan Ketahanan Gempa untuk Struktur Bangunan Gedung dan Non Gedung, Jakarta.

California Seismic Safety Commission (CSSC). (1996). Applied Technology Council 40 Volume 1: Seismic Evaluation and Retrofit of Concrete Buildings.

Satuan Kerja Penyediaan Rumah Susun Strategis (Satker PRRS), Dirjen Penyediaan Perumahan, Kementerian PUPR. (2019). Dokumen perencanaan pembangunan rusunawa Sumatera III.

http://puskim.pu.go.id/Aplikasi/desain_spektra_indonesia_2011 /. Diakses pada tanggal 22 Januari 2020. 